ISSN: 2581-8341

Volume 04 Issue 11 November 2021

DOI: 10.47191/ijcsrr/V4-i11-03, Impact Factor: 5.825

IJCSRR @ 2021

www.ijcsrr.org

\title{
Atherosclerosis [Dhamani Pratichaya] in View of Ayurved
}

\author{
Dr. Sangram Mane ${ }^{1}$, Dr. Trupti Patil-Bhole ${ }^{2}$, Dr. Lata Patil ${ }^{3}$ \\ ${ }^{1}$ Associate Professor, Department of Rognidan Evum Vikruti Vigyan, Bharati Vidyapeeth Deemed (to be)University College of \\ Ayurved Pune-43 \\ ${ }^{2}$ Assistant Professor, Department of Rasashastra Bhaishajya Kalpana Bharati Vidyapeeth Deemed (to be)University College of \\ Ayurved Pune-43 \\ ${ }^{3}$ Assistant Professor, Department of Rognidan Evum Vikruti Vigyan, Bharati Vidyapeeth Deemed (to be)University College of \\ Ayurved Pune-43
}

\begin{abstract}
Atherosclerosis is a disease condition leading to serious consequences such as ischemic heart disease and stroke. Diet and lifestyle changes are most important for the management of this condition. In this review Ayurvedic understanding of this condition is reported. It is termed as Dhamani pratichay by Charak Samhita and Ashtang Sangraha, as a disease of kapha dosha. Appropriate use of a suitable treatment regimen of kapha dosha is helpful to prevent and combat this disease. Nidanparivarjan [discontinuation of causative food and lifestyle] is necessary to prevent blockages. The specific Ayurvedic etiological factors [hetu], early interventions to prevent the condition have been reviewed in this paper. In severe cases, integrative approach must be used.
\end{abstract}

KEYWORDS: Atherosclerosis, Coronary Artery Disease, Dhamani Pratichaya, IHD.

\section{INTRODUCTION}

Atherosclerosis is a disease in which plaque builds up inside arteries, resulting in atherosclerosis. Plaque is formed by fat, cholesterol, calcium, and other substances found in the blood. Plaque hardens and narrows the arteries over time. The passage of oxygen-rich blood to the heart and other regions of the body are hampered as a result.

This condition is known as Dhamanipratichay in Ayurveda. This disease relates to kapha dosha, one of the three dosha which conduct normal and abnormal functions in the human body. The Ayurvedic perspective of atherosclerosis has been elaborated in this review article.

Dhamanipratichay is a chronic illness that requires continuous medical care and management to prevent the risk of complications. In developed countries, the two leading causes of death, myocardial infarction and stroke each may directly result from an arterial system that has been slowly and progressively compromised by years of deterioration. The same thing is indicated by dhamanipratichaya.

\section{AYURVEDIC PERSPECTIVE OF DHAMANIPRATICHAY}

Heart is the main site of rasavaha srotas and ten dhamani are associated with it [1]. Dhamani can be defined as the vessels which carry rasa dhatu and rakta dhatu, [essential nutrients and blood]. Pratichay can be defined as 'atipuran'or coating within the vessels [2]. It is correlated as 'sanga', as a sroto dushti laxan. Meda dhatu accumulates in the arteries, which is vimarga gamana of meda dhatu which is excess in body.

Dhamanipratichay is elaborated as diseases of kapha (one of twenty nanatmaja vikara of kapha) by Acharya vagbhat in doshbhediya adhaya in sutrasthan of Ashtang Sangraha text. Kapha is one of the three dosha forming the body.

Charak samhita has also mentioned dhamanipratichay as one of the kaphaj disorder out of twenty kaphaj nanatmaj vyadhi [3]. Acharya Sushrut and Acharya Charak both have regarded hruday [the heart] as mulasthana of pranvaha and rasavaha srotasa. Chakrapani defined it as Prabhav sthan. It means that this organ is prominent organ of that system. Modern anatomy also relates the heart and lungs to circulatory and respiratory systems, similar to ancient Ayurvedic understanding. 


\section{International Journal of Current Science Research and Review}

ISSN: 2581-8341

Volume 04 Issue 11 November 2021

DOI: 10.47191/ijcsrr/V4-i11-03, Impact Factor: 5.825

IJCSRR@ 2021

Www.ijesrr.org

Because the heart is mostly made up of cardiac muscle tissue that contracts and relaxes constantly, it requires a steady supply of oxygen [ambarpiyush] and nutrients. The coronary arteries are a network of blood channels that supply oxygen and nutrients to the heart muscle tissue.

The aorta, the body's main artery, receives blood from the left ventricle. Near the top of the heart, two coronary arteries arise from the commencement of the aorta. The left major coronary artery is the first segment of the left coronary artery. The left anterior descending coronary artery and the left circumflex coronary artery are two significantly smaller arteries that branch off from it. The left anterior descending coronary artery is located on the front side of the heart, embedded in the surface. The left circumflex coronary artery travels around the left side of the heart and is lodged in the rear surface. When fatty plaque [excessive medadhatu] accumulates to the point of blocking the flow of blood through a coronary artery, beyond the point of obstruction, the heart muscle tissue fed by the coronary artery is deprived of oxygen and nutrients. This section of heart muscle tissue stops working properly. A myocardial infarction, often known as a heart attack, occurs when a coronary artery becomes blocked; causing damage to the cardiac muscle tissue it serves. Heart [hrudaya] is the root organ of Pranvaha and Rasavaha Srotas. Though the disease dhamani pratichay has not been very broadly described in detail; the causes of disturbances of srotasa and its signs are clearly elaborated in Ayurvedic classics.

The general signs of any disturbed srotas [body systems] include one or more from the following phenomena [4].

1] Atipravrutti- This indicates excessive secretion of fluids, like excess bleeding etc

2] Sanga - This indicates consolidation or accumulation. In dhamanipratichay, there is accumulation of fatty plaque [medadhatu] inside arterial walls, narrowing their lumen.

3] Seera/ granthi- This indicates entangling or consolidation/ thickening of vessels. Such phenomenon is seen in varicose veins.

4] Vimargagamana - This indicates improper movement of normal entities [like blood etc] due to obstruction in pathway.

\section{ELABORATION OF AMA CONCEPT}

When ama [undigested part of food] accumulates in the body, signs mentioned above are evident. Each dhatu in the human body has its own agni. It is responsible for metabolism of that particular dhatu. When the medadhatvagni is slowed down, there is obstruction and nourishment of further dhatu [asthi, majja, shukra] is hampered, leading to their kshaya and reduction in their functions. It is reported that if excessive fats accumulate in the body, jatharagni gets enclosed by the body fat and hence the agni intensifies and excess hunger is exhibited by the person. Excess cholesterol and accumulated fats can be correlated as ama. The prime treatment of ama is langhan, i.e. fasting. It leads to digestion of accumulated fat or lipids. When we fast, the digestive 'Agni' gets aggravated and it leads to digestion of accumulated ama. Control on eating habits and complete or partial fasting for cure of kaphaj diseases is regarded as an important lifestyle change by Ayurveda and allopathy both.

\section{TREATMENT OF KAPHAJ VYADHI}

As dhamanipratichay is a kapha related disease, protocol of kaphadoshachikitsa is important for its management.

All the food ingredients which increase kaphadosha, can lead to blockages, if there is excess consumption. This includes sugar, curd, oil, ghee, cheese, butter, sweets, oil seeds etc. All food items which reduce kapha are important to prevent dhamanipratichay. Ginger, garlic, tvak [dalchini], guggulu, kamalnala kshara have been used for managing atherosclerosis.

Treatment regimen includes use of kshar, food having laghu guna, alpa ahara, exercise, mardan/udvartan with help of medicine of rukshaguna, medohar medicines, landhan, consumption of honey etc [5]

\section{PREVENTION OF DHAMANIPRATICHAY}

Regular Vasantika vaman may prevent dhamanipratichaya in persons of kaphaprakruti. Vasant rutu is the time before start of summer season, which is natural time of kaphaprakopa. Vaman is administered only after checking eligibility and agni of a person. Vaman is the best treatment to prevent kapha diseases. Vaman treatment comprises of systematic snehan, swedan and vaman. Snehan includes consumption of high quantities of snehadravya [ghee], and fomentation. This brings doshas in the mahasrotas ie gastrointestinal tract. Then they are physically removed by vamanchikitsa [medicated drugs are administered to induce vomiting]. Ayurvedic classic elaborates about the ways by which Dosha are transported from shakha [body tissues, organs] to koshtha [gastro 


\section{International Journal of Current Science Research and Review}

ISSN: 2581-8341

Volume 04 Issue 11 November 2021

DOI: 10.47191/ijcsrr/V4-i11-03, Impact Factor: 5.825

IJCSRR@ 2021

www.ijesrr.org

-intestinal tract]. The ways are vruddhi [increasing the dosha], abhishyanda. The dosha causing accumulation can be removed from time to time by classical VasantikaVaman.

\section{Stress management by Ayurveda}

It may be normal to have blockages at an older age, but sudden contraction of coronary arteries (even in young adults) due to stress leads to sudden ischemic attack. Stress causes sudden contraction of arteries and it may lead to acute attack of IHD [6, 7].

Stress is a major contributing factor for diseases like MI and stroke. Proper stress management is essential. Following urges must be controlled or avoided to have a healthy life. Heart is also the site of 'mana', and hence the thoughts and subsequent deeds affect our heart. Ayurveda elaborates the dharaniya vega as follows [8]- lobha [desires], irsha [getting envy], dvesha [hatred], matsar [jealosy], raga [anger]. All these should never be expressed and kept in mind. To tackle unnecessary stress one should refrain from (control or hold) these dharaniya vega [9]. Medicines such as manasmitra vataka, jatamansi, ashwagandha etc are prescribed to curb excessive stress.

\section{CONCLUSION}

Dhamanipratichay arises mainly due to improper diet and improper lifestyle. This leads to thickening of arteries (dhamanipratichay) resulting in angio-obstruction and angina. Patients of Kapha dominant prakruti and obese persons are more prone to this condition. Causative factors related to diet, lifestyle and mind are found in the patients.

Samprapti of Dhamanipratichay can be seen in patients of ischemic heart disease which is similar to hruta shul described by Acharya Sushrut. Excessive consumption of Madhur (sweet), Amla (sour), Lavan (salty) foods are prominently done by patients. Excessive consumption of guru (heavy), snigdha (oily/fatty), sheeta (cold), vidahi (spicy), abhishyandi (sticky) food is observed in patients. Excess worry and fear are found maximally as hetu in a number of cases [10].

Atimatrashan (excess food intake), vegadharan (holding the natural urges), avyayam (sedentary lifestyle) and vyasan (addictions) are dominantly seen. Ayurveda is very much concerned about conservation of health. Ayurveda presumes that improper dietary habits give rise to various disorders.

With practice of dietary measures recommended in Ayurveda while elaborating medoroga chikitsa will definitely beneficial in weight reduction. It will help to minimize fat deposition. We can avoid the occurrence of dhamanipratichay by improving lifestyle and by eradicating unnecessary stress by following some simple rules.

It is advisable to take a strict vegetarian low fat diet. The best recommended diet includes cooked sprouted mudga, mudgayusha, cow's milk [instead of buffalo milk]. Regular vyayam (exercise) helps to eliminate body fat. Ayurveda does not recommend consumption of raw salads, raw sprouts, and excess amount of raw fresh juices [swaras] of any fruits or veggies. Eating cooked food is recommended. The general allowed dose of 'swarasa' (fresh extracted juice) obtained from freshly collected fruits/veggies is 20 $\mathrm{ml}$ whereas that of 'swarasa' prepared from dried plant is $40 \mathrm{ml}$. [11]. Hence the use of any raw juices like bottle gourd or dudhi, should not be in excess dose. The excess dose may harm the patient. The reason is that fresh extracted juice is the heaviest form most tedious to digest according to Ayurveda. Excess consumption of swaras leads to Ama formation and it harms rather than helping. Saindhav Lavan (rock salt), food having katu rasa (pungent taste) and tikta rasa (bitter taste) are considered important in diet for patients suffering from dhamanipratichay. Light food (of laghu guna) is useful.

Ayurved recommends ardha shakti vyayam in shita kala and vasant rutu for persons having good strength, and for persons who consume unctuous food[12]. Ardh shakti vyayam means occurrence of sweat on forehead by exercise, this may take variable time in different persons. Once this sign appears, exercise should be stopped for that day. In other seasons, Ayurveda recommends minimal exercise. This indicates that summer season is not the correct time for very strenuous exercise. Very strenuous exercise in hot climates may stress the heart and may lead to heart trouble. This is evident in general practice, where persons doing very strenuous exercises also suffer from sudden cardiac arrest, due to unknown cause as per modern medical science.

Vyasan like cigarette, tobacco are gara visha. Cigarette smokers tend to have high blood pressure. 


\section{International Journal of Current Science Research and Review}

ISSN: 2581-8341

Volume 04 Issue 11 November 2021

DOI: 10.47191/ijesrr/V4-i11-03, Impact Factor: 5.825

IJCSRR@ 2021

Www.ijcsrr.org

It is advised to avoid vegadharan of adharniya vegas. Forceful retention of natural urges like thirst [13], cough [14], tachypnoea due to exercise or efforts [15], tears [16], semen [17] have been regarded as causative factors for hrud roga by Ayurvedic classic Ashtanga Hrudaya. Forceful retention of these urges may pressurize the heart and its vessels. Heart is considered as the seat of mind [manas]. Hence stressful situations for the mind are considered as causes for heart related problems. Speaking loudly, bursts of anger should be avoided, mithyayoga of vacha (loud speech) produces elevation in blood pressure. Laughter is the best medicine to overcome stress. Meditation and performing yoga can help to reduce breathlessness and other heart related ailments.

\section{REFERENCES}

1. Sushrut samhita of Acharya Sushruta, Commentary by Ghanekar BG, Sharirsthana, 9/2, pp 229

2. Ashtangsangraha of Vagbhat, sutrasthan saroj hindi vyakhya sahit Commentary Edited by Dr. Rvidatta Tripathi. Sutrasthan sthana, 20/13. Varanasi: Choukhambha Sanskrit pratishsthan 1999. p. 388.

3. Agnivesha, Charaka Samhita with Vidyotini Hindi Commentary Edited by Dr. Gorakhanatha Chaturvedi. Sutrasthan sthana, 20/17. Varanasi: Choukhambha Bharati Academy; 1988. p. 404

4. Agnivesha, Charaka Samhita with Vidyotini Hindi Commentary Edited by Dr. Gorakhanatha Chaturvedi. Vimansthana, 05/24. Varanasi: Choukhambha Bharati Academy; 1988. p. 714

5. Sarth Vaghbhat, vaghbhat krut Ashtanghruday Edited by Dr.Ganesh Krushna Garde. Sutrasthan, 13/12. Pune: Anmol Prakashan; 2007. p. 60

6. Kotlęga D, Gołąb-Janowska M, Masztalewicz M, Ciećwież S, Nowacki P. The emotional stress and risk of ischemic stroke. Neurol Neurochir Pol. 2016 Jul-Aug; 50(4):265-70. doi: 10.1016/j.pjnns.2016.03.006. Epub 2016 Mar 23. PMID: 27375141.]

7. Vuletić V, Sapina L, Lozert M, Lezaić Z, Morović S. Anxiety and depressive symptoms in acute ischemic stroke. Acta Clin Croat. 2012 Jun; 51(2):243-6. PMID: 23115949.]

8. Sarth Vaghbhat, vaghbhat krut Ashtanghruday Edited by Dr.Ganesh Krushna Garde. Sutrasthan, 4/25. Pune: Anmol Prakashan; 2007. p. 16

9. Sarth Vaghbhat, vaghbhat krut Ashtanghruday Edited by Dr.Ganesh Krushna Garde. Sutrasthan, 4/1. Pune: Anmol Prakashan; 2007. p. 15

10. Agnivesha, Charaka Samhita with Vidyotini Hindi Commentary Edited by Dr. Gorakhanatha Chaturvedi. Sutrasthan sthana, 17/73. Varanasi: Choukhambha Bharati Academy; 1988. p. 350. 12. Sarth Vaghbhat, vaghbhat krut Ashtanghruday Edited by Dr.Ganesh Krushna Garde. Sutrasthan, 11/40. Pune: Anmol Prakashan; 2007. p. 54

11. Savrikar SS, Ravishankar B. BhaishajyaKalpanaa - the Ayurvedic pharmaceutics - an overview. Afr J Tradit Complement Altern Med. 2010; 7(3):174-184. Published 2010 Apr 3. doi:10.4314/ajtcam.v7i3.54773].

12. Sarth Vaghbhat, vaghbhat krut Ashtanghruday Edited by Dr.Ganesh Krushna Garde. Sutrasthan, 02/11. Pune: Anmol Prakashan; 2007. p. 8

13. Sarth Vaghbhat, vaghbhat krut Ashtanghruday Edited by Dr.Ganesh Krushna Garde. Sutrasthan, 04/11. Pune: Anmol Prakashan; 2007. p. 15

14. Sarth Vaghbhat, vaghbhat krut Ashtanghruday Edited by Dr.Ganesh Krushna Garde. Sutrasthan, 04/14. Pune: Anmol Prakashan; 2007. p. 16

15. Sarth Vaghbhat, vaghbhat krut Ashtanghruday Edited by Dr.Ganesh Krushna Garde. Sutrasthan, 04/15. Pune: Anmol Prakashan; 2007. p. 16,

16. Sarth Vaghbhat, vaghbhat krut Ashtanghruday Edited by Dr.Ganesh Krushna Garde. Sutrasthan, 04/17. Pune: Anmol Prakashan; 2007. p. 16

17. Sarth Vaghbhat, vaghbhat krut Ashtanghruday Edited by Dr.Ganesh Krushna Garde. Sutrasthan, 04/20. Pune: Anmol Prakashan; 2007. p. 16

Cite this Article: Dr. Sangram Mane, Dr. Trupti Patil-Bhole, Dr. Lata Patil (2021). Atherosclerosis [Dhamani Pratichaya] in View of Ayurved. International Journal of Current Science Research and Review, 4(11), 1491-1494 